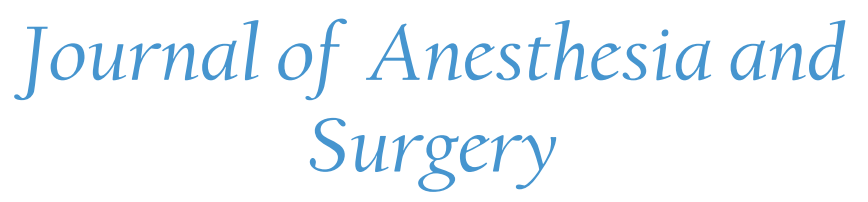

\title{
The Influence of Targeting Central Venous Pressure (CVP) on Early Graft Function after Living Donor Kidney Transplantation
}

\author{
Mojsova-Mijovska $\mathbf{M}^{1 *}$, Gavrilovska $\mathbf{A}^{1}$, Srceva-Jovanovski $\mathbf{M}^{1}$, Temelkovska $\mathbf{M}^{1}$, Stavridis $\mathbf{S}^{2}$, \\ Spasovski $\mathbf{G}^{3}$
}

${ }^{1}$ University Clinic of Traumatology, Orthopedia, Anesthesia, Intensive Care and Emergancy Center, Macedonia

${ }^{2}$ University Clinic of Urology, Macedonia

${ }^{3}$ University Clinic of Nephrology, Macedonia

"Corresponding author: Maja Mojsova Mijovska, M.D, Ph.D, University Clinic of Traumatology, Orthopedia, Anesthesia, Reanimation, Intensive Care and Emergency Center Skopje, R. Macedonia, E-mail: majamojsova777@gmail.com

\begin{abstract}
Introduction: Early graft function is very important and can be achieved with an adequate intraopeartive perfusion characteristics of the graft and urine output. The goal of this study was to examine the influence of targeting CVP on early graft function.

Material and methods: After approval of Ethical committee of the Medical Faculty-Skopje we obtained inform consent of 60 patients ASA 2 - 3 undergoing renal transplantation of living-related person in the Clinic of Urology-Skopje. A prospective clinical study which was performed in the period of 2 years. They were divided in 2 groups of thirty patients: group A receiving normal saline intraoperativly targeting for CVP $15 \mathrm{mmHg}$ until vascular clamps were off and group $\mathrm{B}$ receiving normal saline $10 \mathrm{ml} / \mathrm{kg} / \mathrm{h}$. We recorded onset of diuresis and total urine output from unclamping the renal vessels to the end of the surgery in both groups and postoperative serum, urine creatinin and FENa \% in 3 times $(3,12,36$ hours).

Results: The onset of diuresis in seconds was insignificantly longer in group B p $>0.05(p=0.31)$ we didn't find any statistical differences in postoperative serum creatinin in both groups.

Conclusion: Our study didn't show any benefit from targeting CVP to $15 \mathrm{mmHg}$. We couldn't find any significant differences on onset of diuresis and urine output after the unclamping the vessels.
\end{abstract}

Received date: March 9, 2017

Accepted date: March 23, 2017

Published date: March 30, 2017

Citation: Mijovska M.M., et al. The Influence of Targeting Central Venous Pressure (CVP) on Early Graft Function after Living Donor Kidney Transplantation. (2017) J Anesth Surg 4(1): 32- 35.

DOI: $10.15436 / 2377-1364.17 .068$

Keywords: CVP; Early graft function; Kidney transplantation

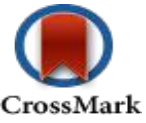

\section{Introduction}

Kidney transplantation is the best choice for patients in end-stage renal disease (ERSD). It becomes a routine intervention nowadays. Early graft function is very important and it's always a good predictor of the survival of the graft in the new environment and it can be achieved with adequate intraoperative perfusion. Early graft malfunction has been associated with decreased graft survival and increased recipient complication ${ }^{[1-5]}$. A lot of studies have examined specific value of the perioperative central venous pressure (CVP) that may reduce the risk of postoperative graft failure ${ }^{[7-10]}$. Intra-operative volume expansion is associated with increased renal blood flow and an improvement in immediate graft function ${ }^{[12,13]}$. Immediate function is associat- ed with increased graft survival and lower patient mortality ${ }^{[13-16]}$. It is well known that the most important measure to improve immediate graft function is to maintain an adequate intravascular volume.

To our knowledge, no published studies have validated the relationship between time course of volume expansion and the period of renal ischemia and beside the recommendation for CVP values, we still don't have an answer for exact recommended value of CVP. Recommendations for the intraopertive hydration are not clear ${ }^{[8,13,16]}$. Although this recommendations have wide range of CVP between $7-17 \mathrm{mmHg}$ and mean arterial pressure of $80-90 \mathrm{mmHg}^{[8,16,17]}$. Volume expansion is associated with better graft flow and early graft function ${ }^{[16-19]}$. Previous studies have examined specific values of perioperative central 
venous (CVP) that may reduce the risk of postoperative graft failure. In the postoperative period the biochemical parameters are still most important measurement for evaluation of recovery of the graft in new environment. This led for need of protocols regarding intraoperative management and hydration during the intraoperative. The goal of this study was to examine the influence of targeting CVP of $15 \mathrm{mmHg}$ on onset of duresis and biochemical parameters in early postoperative period.

\section{Methods}

After approval of Ethical committee of the Medical Faculty-Skopje we obtained inform consent of 60 patients undergoing renal transplantation of living-related person in the Clinic of Urology-Skopje. A prospective clinical study which was performed in the period of 2 years. They were divided in 2 groups: group A receiving normal saline intraoperativly targeting for CVP $15 \mathrm{mmHg}$ until vascular clamps were off and group $\mathrm{B}$ receiving normal saline $10 \mathrm{ml} / \mathrm{kg} / \mathrm{h}$. The exclusion criteria were: severe left ventricular impairment, cardiomiopathy with ejection fraction bellow $50 \%$, problem with coagulation, excessive bleeding during the operation, resistant graft arterial spasm or any other surgical difficulty.

All transplantations in this study were performed by the same surgical team. All patients underwent full medical and surgical history, and routine laboratory investigations (i.e., blood $\mathrm{Hb}$, plasma proteins, coagulation status, serum electrolytes, blood glucose, lactate, arterial blood gases, chest radiograph, and echocardiography). All patients underwent preoperative hemodialysis 24 hours before renal transplant surgery.

\section{Protocol for anesthesia}

Standard monitoring ECG in 5 leads, noninvasive blood pressure and pulse oximetry before the induction were recorded. Before the induction the epidural catheter was inserted on level L2-L3 or L3-L4 and it was given a test dose of bupivacain $10 \mathrm{mg}$. We didn't use the epidural catheter until the end of surgery. At the end of the intervention we gave $100 \mathrm{mcg}$ fentanyl and $20 \mathrm{mg}$ of bupivacain in volume of $10 \mathrm{ml}$ to avoid any interference with intraoperative hemodynamics. For induction we used remifentanyl in dose $0.5 \mathrm{mcg} / \mathrm{kg}$ and propofol 2 $\mathrm{mg} / \mathrm{kg}$ and the intubation is facilitated with dose of atrcurium $0.5 \mathrm{mg} / \mathrm{kg}$ and maintaining of anesthesia was with remifentanyl $0.25 \mathrm{mcg} / \mathrm{kg}$ and propofol $0.5-1 \mathrm{mg} / \mathrm{kg}$ depending on depth of anesthesia which was recorded with entropy electrodes. Patients were ventilated with mixed oxygen/air $50-50 \%$ with tidal volume of $7-9 \mathrm{ml} / \mathrm{kg}$ and end-tidal $\mathrm{CO}_{2}$ between $35-40 \mathrm{mmHg}$ (Datex-Ohmeda Avance S-5). After the induction central venous catheter aseptically was placed in the internal jugular vein and pressure was transdused and recorded. For measuring invasive arterial pressure an arterial catheter was placed in a radial is and it was recorded. We noted the time of urine onset (sec) and the total amount of diuresis in ml until end of the surgery. In postoperative period we measured the total urine output $(\mathrm{ml})$, the level of plasma and urine creatinine $(\mathrm{mmol} / \mathrm{L})$ and fraction excretion of sodium in 3 times -3.12 and 36 hours after the surgery.

\section{Statistical analysis}

Statistical analysis was performed with SPSS (version 9.0 for Windows, SPSS, Chicago, IL). Continuous data are de- scribed as mean $\pm \mathrm{SD}$ and categorical variables are given as percentages. All data were tested for normality using the method of Kolmogorov-Smirnov. Intergroup differences in demographic, perioperative hemodynamic values, and laboratory values were compared using unpaired Student $t$-test. Mann-Whitney $U$ - test was used for unpaired nonparametric data, including the volume of crystalloid infused, urine output, and the onset of diuresis. Percentages were compared by $\mathrm{X}^{2}$ contingency analysis. $\mathrm{P}<$ 0.05 was considered to be significant. Mean group differences and their $95 \%$ confidence intervals were calculated to determine which of the specific variables differed between groups. If the $95 \%$ confidence interval includes 0 , it indicates no significant difference between groups.

\section{Results}

All the patients underwent for hemodialysis 24 hours before surgery except 4 patients in group A who had not required hemodialysis and 2 patients in group B. Mean arterial preoperative blood $\mathrm{Hb}$ and serum creatinine were similar in both groups. Average $\mathrm{Hb}$ in group A was $116.73 \pm 19.07$ and for group B was $112.93 \pm 17.19$. Average creatinine for group A was $632.63 \pm$ 187.00 and for group B 556.52 \pm 164.14 . The demographic and operative data are shown in table 1.

Table 1: Demographic and operative data of both groups.

\begin{tabular}{|l|l|l|}
\hline & Group A & Group B \\
\hline Age(years) & $37.87 \pm 9.32$ & $41.47 \pm 10.25$ \\
\hline Sex F/M & $15 / 15$ & $17 / 13$ \\
\hline Body weight kg & $74.17 \pm 10.92$ & $70.83 \pm 11.83$ \\
\hline Duration of surgery(min) & $236.67 \pm 40.33$ & $250.83 \pm 61.65$ \\
\hline Cold ischemia(min) & $210.10 \pm 33.98$ & $221.43 \pm 35.62$ \\
\hline Warm ischemia( sec) & $170.30 \pm 39.34$ & $184.20 \pm 38.13$ \\
\hline Months on hemodialysis & $12.17 \pm 13.32$ & $17.95 \pm 31.71$ \\
\hline Comorbidites & \multicolumn{2}{|l}{} \\
\hline 1. None & 11 & 16 \\
\hline 2. hipertension & 16 & 3 \\
\hline $\begin{array}{l}\text { 3. Hypertension and diabetes } \\
\text { melitus }\end{array}$ & 3 & \\
\hline & & \multicolumn{2}{|l}{} \\
\hline
\end{tabular}

Values are mean \pm sd; group A is CVP 15 target group, group B constant infusion group

The onset of diuresis and urine output at the end of the surgery showed no statistical differences between the groups but in 5 patients in control group we didn't achieve urine output at the end of the surgery (Table 2)

Table 2: The onset of diuresis and urine output at the end of the surgery.

\begin{tabular}{|l|l|l|l|l|l|l|l|}
\hline $\begin{array}{l}\text { Pa- } \\
\text { rame- } \\
\text { ter }\end{array}$ & $\begin{array}{l}\text { Rank } \\
\text { Sum } \\
\text { Group } \\
\text { A }\end{array}$ & $\begin{array}{l}\text { Rank } \\
\text { Sum } \\
\text { Group } \\
\text { B }\end{array}$ & $\mathbf{U}$ & $\mathbf{Z}$ & $\begin{array}{l}\text { p- } \\
\text { level }\end{array}$ & $\begin{array}{l}\text { Nalid } \\
\text { Group } \\
\text { A }\end{array}$ & $\begin{array}{l}\text { Valid } \\
\text { N } \\
\text { Group } \\
\text { B }\end{array}$ \\
\hline $\begin{array}{l}\text { Urine } \\
\text { output }\end{array}$ & 829.50 & 710.50 & 364.50 & -0.18 & 0.86 & 30 & 25 \\
\hline $\begin{array}{l}\text { Onset } \\
\text { of di- } \\
\text { uresis } \\
\text { (sec) }\end{array}$ & 780.00 & 760.00 & 315.00 & -1.01 & 0.31 & 30 & 25 \\
\hline
\end{tabular}


The creatinine levels in serum $(\mathrm{mmol} / \mathrm{L})$ in postoperative period for both groups in 3.12 and 36 hours are showed in (the Table 3). Between average values of serum creatinin in relation between 3.12 and 36 hours for $p>0.05$ we didn't find any statistical differences

Table 3: Serum cretinin $(\mathrm{mmol} / \mathrm{L})$ in 3.12 and 36 hours after the surgery.

\begin{tabular}{|c|c|l|c|c|c|c|c|c|}
\hline & group & R1 & $\mathbf{1}\} \mathbf{4 5 4 . 6 9}$ & $\mathbf{\{ 2}\} \mathbf{3 5 2 . 8 4}$ & $\mathbf{3}\} \mathbf{2 2 0 . 6 4}$ & $\{\mathbf{4}\} \mathbf{4 5 6 . 8 7}$ & $\{\mathbf{5}\} \mathbf{3 5 2 . 8 8}$ & {$[\mathbf{6}\} \mathbf{2 3 8 . 6 8}$} \\
\hline 1. & A & Creatinin/3h & & 0.000 & 0.000 & 0.97 & 0.009 & 0.000 \\
\hline 2. & A & Creatinin /12h & 0.000 & & 0.000 & 0.008 & 0.99 & 0.004 \\
\hline 3. & A & Creatin /36h & 0.000 & 0.000 & & 0.000 & 0.000 & 0.77 \\
\hline 4. & B & Creatinin/3h & 0.97 & 0.008 & 0.000 & & 0.000 & 0.000 \\
\hline 5. & B & Creatinin /12h & 0.009 & 0.99 & 0.0009 & 0.000 & & 0.000 \\
\hline 6. & B & Creatin /36h & 0.000 & 0.004 & 0.77 & 0.000 & 0.000 & \\
\hline
\end{tabular}

The creatinine levels in urine $(\mathrm{mmol} / \mathrm{L})$ in postoperative period for both groups in 3.12 and 36 hours are showed in (the Table 4). Between average values of urine creatinin in relation between 3.12 and 36 hours for $p>0.05$ we didn't find any statistical differences.

Table 4: urine cretinin $(\mathrm{mmol} / \mathrm{L})$ in 3.12 and 36 hours after the surgery.

\begin{tabular}{|c|c|l|c|c|c|c|c|c|}
\hline & group & $\mathbf{R 1}$ & $\{\mathbf{1}\} \mathbf{1 8 . 1 4}$ & $\{\mathbf{2}\} \mathbf{1 7 . 9 2}$ & $\{\mathbf{3}\} \mathbf{2 4 . 8 2}$ & $\{\mathbf{4}\} \mathbf{9 . 2 9}$ & $\{\mathbf{5}\} \mathbf{1 5 . 4 6}$ & {$[\mathbf{6}\} \mathbf{1 8 . 4 8}$} \\
\hline 1. & $\mathrm{~A}$ & Creat/3h/urine & & 0.96 & 0.14 & 0.17 & 0.61 & 0.95 \\
\hline 2. & $\mathrm{~A}$ & Creat $/ 12 \mathrm{~h} /$ urine & 0.96 & & 0.13 & 0.10 & 0.70 & 0.92 \\
\hline 3. & $\mathrm{~A}$ & Creat $/ 36 \mathrm{~h} /$ urine & 0.14 & 0.13 & & 0.003 & 0.08 & 0.33 \\
\hline 4. & $\mathrm{~B}$ & Creat/3h/urine & 0.17 & 0.10 & 0.003 & & 0.17 & 0.04 \\
\hline 5. & $\mathrm{~B}$ & Creat $/ 12 \mathrm{~h} /$ urine & 0.61 & 0.70 & 0.08 & 0.17 & & 0.50 \\
\hline 6. & $\mathrm{~B}$ & Creat $/ 36 \mathrm{~h} /$ urine & 0.95 & 0.92 & 0.33 & 0.04 & 0.50 & \\
\hline
\end{tabular}

The fraction extraction of sodium in percentage (FENa \%) in postoperative period for both groups in 3.12 and 36 hours are showed in (the Table 5). Between average values of FENa \% in relation between 3.12 and 36 hours for $p>0.05$ we didn't find any statistical differences.

Table 5: urine cretinin $(\mathrm{mmol} / \mathrm{L})$ in 3.12 and 36 hours after the surgery.

\begin{tabular}{|c|c|l|c|c|c|c|c|c|}
\hline & group & R1 & $\{\mathbf{1}\}$ & $\{\mathbf{2}\}$ & $\{\mathbf{3}\}$ & $\{\mathbf{4}\}$ & $\{\mathbf{5}\}$ & $\mathbf{6 6}\}$ \\
\hline 1. & A & FENa \%/3h & & 0.004 & 0.000 & 0.85 & 0.003 & 0.000 \\
\hline 2. & A & FENa \%/12h & 0.004 & & 0.10 & 0.06 & 0.56 & 0.059 \\
\hline 3. & A & FENa \%/36h & 0.000 & 0.10 & & 0.002 & 0.66 & 0.63 \\
\hline 4. & B & FENa \%/3h & 0.85 & 0.06 & 0.002 & & 0.0004 & 0.0000 \\
\hline 5. & B & FENa \%/12h & 0.003 & 0.56 & 0.66 & 0.0004 & & 0.15 \\
\hline 6. & B & FENa \%/36h & 0.000 & 0.06 & 0.63 & 0.000 & 0.15 & \\
\hline
\end{tabular}

\section{Discussion}

Many studies suggest that during kidney transplantation the systolic and diastolic should be higher than $120 / 85 \mathrm{mmHg}$. They also suggest that the MAP should be higher than $95 \mathrm{mmHg}$ and CVP above $10 \mathrm{mmHg}^{[10-16]}$. These values are favorable to ensure maximal filling pressure of the graft and its fast recovery. Prolonged arterial hypotension can led to graft hypoperfusion and after that to prolonged time for graft recovery and delay graft function ${ }^{[17-19]}$. In both groups we didn't had any episode of hypotension and there was no need for vasopresors. Intraoperative volume expansion is associated with increased renal blood flow and better immediate graft function ${ }^{[15,16]}$. Early graft malfunction has been associated with decreased graft survival and increased recipient complication ${ }^{[12]}$. Earlier at al showed that maximal hydration during anesthesia up to $100 \mathrm{ml} / \mathrm{kg}$ and $30 \mathrm{ml} /$ $\mathrm{kg} / \mathrm{h}$ and CVP 10 - 17 were associated with improved early graft function $^{[8]}$.

Many of the clinical trials showed that that regimen targeting CVP before cross-clamp of the donor kidney provides a more favorable outcome ${ }^{[10,15,17]}$. They showed that high hydration regime provides more turgid graft and faster onset of diuresis. The time of surgery, cold ischemia and warm ischemia were similar in both groups. Our study didn't show any benefit from targeting CVP to $15 \mathrm{mmHg}$. We couldn't find any significant differences on onset of diuresis and urine output after the unclamping the vessels. In 5 patients in control group we didn't achieved a urine output at the end of the surgery. Decreased value of serum creatinine in postoperative period is good sign of fast recovery of the graft. In our study 36hours after the transplantation 9 patients in group A had normal values of serum cratinine and 6 patients in group B. The average values of serum cratinine for group A was $220.64 \pm 158.10$ and $238.68 \pm 131.50$ for group B In postoperative biochemical parameters we had no statistical 
difference between the average values of cratinine in serum and in urine. After renal transplantation low urinary sodium concentration (UNa) has been used to diagnose acute rejection (AR), for the early phase of AR is often associated with reduced renal perfusion. Early postoperative graft failure without low UN favors the diagnosis of ischemic tubular damage (ATN). With fraction extraction of the sodium we can make a distinction between prerenal and renal failure of the kidney in new environment. In our study in both groups in time 3 hours after surgery only $3.33 \%$ of the patients had prerenal failure. In 12 hours after surgery in group A we had only 1 patient but in group B 4 patients $(13.33 \%)$ with prerenal failure. In the postoperative period the hydration regime is based in iso balance administration of normal saline. This opens a dilemma regarding the intraoperative hydration regime and how it can influence the postoperative recovery of the kidney. Drops in FENa \% should be interpreted in conjunction with state of fluid balance, particularly in the early diuretic phase.

\section{Conclusion}

This study shows that there isn't any statistical difference between the groups however in group B we had 5 patients with no diuresis at the end of the surgery. Our study didn't show any benefit of targeting CVP. This study has limitations. We only evaluated onset of the diuresis and have not considered whether there are long-term benefits. There is need for larger study to confirm if there is true benefit (improved long-term outcomes).

\section{References}

1. Wolfe, R.A., Ashby, V.B., Milford, E.L., et al. Comparison of mortality in all patients on dialysis, patients on dialysis awaiting transplantation, and recipientsof a first cadaveric transplant. (1999) N Engl J Med 341(23): 1725-1730.

Pubmed I Crossref I Others

2. Rabbat, C.G., Thorpe, K.E., Russell, J.D., et al. Comparison of mortality risk for dialysis patients and cadaveric first renal transplant recipients in Ontario, Canada. (2000) J Am Soc Nephrol 11(5): 917-922. Pubmed

3. Ojo, A.O., Hanson, J.A., Meier-Kriesche, H., et al. Survival in recipients of marginal cadaveric donor kidneys compared with other recipients and wait-listed transplant candidates. (2001) J Am Soc Nephrol 12(3): 589-597.

Pubmed I Others

4. Meier-Kriesche, H.U., Port, F.K., Ojo, A.O., et al. Effect of waiting time on renal transplant outcome. (2000) Kidney Int 58(3): 1311-1317. Pubmed I Crossref I Others

5. Kim, S.Y., Huh, K.H., Lee, J.R., et al. Comparison of the effects of normal saline versus Plasmalyte on acid-base balance during living donor kidney transplantation using the Stewart and base excess methods. (2013) Transplant Proc 45(6): 2191-2196.

Pubmed I Crossref I Others

6. Dawidson, I., Berlgin, E., Brynger, H., et al. Intravascular volumes and colloid dynamics in relation to fluid management in living-related kidney donors and recipients. (1987) Crit Care Med 15(7): 631-636.

Pubmed I Crossref
7. Dawidson, I., Sandor, Z.F., Coorpender, L., et al. Intraoperative albumin administration affects the outcome of cadaver renal transplantation. (1992) Transplantation 53(4): 774-784.

Pubmed I Crossref I Others

8. Carlier, M., Squifflet, J.P., Pirson, Y., et al. Maximal hydration during anesthesia increases pulmonary arterial pressures and improves early function of human renal transplants. (1982) Transplantation 34(4):201204.

Pubmed I Crossref I Others

9. Caldwell, et al. Kidney transplantation. In Cook, D.R., Davis, P., (eds): Anesthetic Principles for Organ Transplantation. (1995) New York Raven Press 183.

10. Willms, C.D., Dawidson, I.J., Dickerman, R., et al. Intraoperative blood volume expansion induces primary function after renal transplantation: a study of 96 paired cadaver kidneys. (1991) Transplant Proc 23(1 pt 2): 1338-1339.

Pubmed I Others

11. Dawidson, I., Ar'Rajab, A., Dickerman, R., et al. Perioperative albumin and verapamil improve early outcome after cadaver renal transplantation. (1994) Transplant Proc 26(6): 3100-3101.

Pubmed I Others

12. O'Malley, C.N., Frumento, R.J., Bennett-Guerrero, E. Intravenous fluid therapy in renal transplant recipients: results of a US survey. (2002) Transplant Proc 34(8): 3142-3145.

Pubmed I Crossref I Others

13. Yee, J., Parasuraman, R., Narins, R.G. Selective review of key preoperative renal electrolyte disturbances in chronic renal failure patients: preoperative cardio pulmonary evaluation and management. (1999) Chest 115 (5 suppl): $149 \mathrm{~s}-57 \mathrm{~s}$.

Pubmed I Crossref

14. Toth, M., Reti, V., Gondos, T. Effect of recipient's perioperative parameters on the outcome of kidney transplantation. (1998) Clin Transplant 12(6): 511-517.

Pubmed I Others

15. Othman, M.M., Ismael, A.Z., Hammouda, G.E. The impact of maximal crystalloid hidration on early graft function during kidney transplantation. (2010) Anesth Analg 110(5): 1440-1446.

Pubmed I Others

16. Khajavi, M.R., Etezadi, F., Moharari, R.S., et al. Effects of normal saline vs. Lactated Ringer's during renal transplantation. (2008) Ren Fail 30(5): 535-539.

Pubmed I Crossref I Others

17. Hadimioglu, N., Ertug, Z., Yegin, A., et al. Correlation of peripheral venous and central venous pressure in kidney recipients. (2006) Transplant Proc 38(2): 440-442.

Pubmed I Crossref I Others

18. Vaupshas, H.J., Levy, M. Distribution of saline following acute volume loading: postural effects. (1990) Clin Invest Med 13(4): 165-177. Pubmed I Others

19. Hadimioglu, N., Ertug, Z., Yegin, A., et al. Correlation of peripheral venous and central venous pressure in kidney recipients. (2006) Transplant Proc 38(2): 440-442.

Pubmed I Crossref I Others
Ommega Online Publishers

Journal Title: Journal of Anesthesia and Surgery (JAS)

Journal Short Name: J Anesth Surg
Journal ISSN: 2377-1364

E-mail: anestheisa@ommegaonline.com

Website: www.ommegaonline.org 